inches; we made a "duck" island; and finally, we created two smaller ponds three to four feet deep, and covering from one to one and a half acres each, several yards upstream. The normal watershed is probably 75100 acres, with runoff from 150-175 acres in times of flooding.

We received some assistance with our project- $\$ 125.00$ from P.F.R.A. and $\$ 147.00$ from the municipality. The rest of our expenses, which we met ourselves, including the cost of a mile-long fire-break, totalled over $\$ 1300.00$. We feel that our investment has provided a very pleasant spot for summer outings, and we hope that it will prove to be really worthwhile in encouraging wildlife. Comments and visitors will always be welcome, as well as any suggestions that our friends and readers may have for improving the sanctuary.

\section{JEFFERIES INGLEWOOD BIRD SANCTUARY}

By Pearl Guest, Regina

It was one of those fickle days of sunshine and showers during the summer of 1958 when my brother nosed the car through traffic and towards the south-eastern section of Calgary. The Inglewood. Bird Sanctuary was our destination. Entering through a small gate, John observed that it was like walking into another world as we followed a footpath through the trees and down to the edge of a pond where flocks of Canada geese and different kinds of ducks cruised leisurely on the water. They all paused at our approach and then headed hopefuly towards us but, thoughtlessly unprepared, we had little to feed them.

Athwart the water lay a small dam topped by a footbridge. Crossing on this, we came on to what turned out to be a peninsula bordered on the west by the spring-fed pond and on the east by the Bow River. Following the shore line, we came to the isolated nesting area and a fish fingerling pond. Exploring eastwards, we came to the wide river and turning again, discovered a winding path through the tall old trees that led us back to the dam.

Robins gave little heed to our passing, but a squirrel voiced garrulous objection at the intrusion. Somewhere a veery sang and I was surprised at his boldness as in our Hid- den Valley Sanctuary I had become accustomed to veeries as shy retiring birds singing in the twilight. But not so with this songster whose bell-like notes rang out across the water, accentuating the silence and seclusion of the woodland.

Threatening clouds forced our reluctant return to the car and we drove back to the big brick house which is the Headquarters of the Sanctuary. There we were welcomed by the host of the mansion, Mr. George - Spargo, Secretary-Manager of the Alberta Fish and Game League. In the ensuing conversation, we learned that the late Ed. Jefferies had donated this residence and its immediate land to the League for its permanent home, and that it administered the affairs of the 120-acre sanctuary. Actually the haven has been in existence for many years, for Selby Walker and Mr. Pickering were interested in wildlife, and waterfowl have wintered here since 1907, taking advantage of the open water below the ever-flowing springs. Winter food is supplied to the waterfowl by the bread firms and grain companies of Calgary.

Standing at the window watching the rain come down in sheets, our host told us that the big cottonwoods were sixty years old. When some of them were destroyed by beaver the busy builders were caught and moved elsewhere. Spruce trees have been planted to offer solid protection for the birds, especially during the winter, and Mr. Spargo told us that the local Boy Scouts had provided 150 bird houses. He told us, too, of the interesting personalities of some of the birds using the Sanctuary and of the skill with which some of them hide their nests. One duck, a permanent resident, is called "Cleopatra" for the handsome drakes seem to find her irresistible.

There was so much of interest at the Jefferies Inglewood Bird Sanctuary that I would urge our Saskatchewan members to explore the sanctuary when they visit the city of Calgary.

ED. NOTE: We should like to express our appreciation to the Alberta Fish and Game Association for taking on the responsibility of preserving this beauty spot in the heart of industrial Calgary. We hope that other organizations and individuals will take active steps to preserve areas of natural beauty in their localities as the Alberta $F$ ish and Game Association in Calgary and Ernie Symons at Rocanville 